Meta

Journal des traducteurs

Translators' Journal

\title{
Brief History of Science Translation in China
}

\section{$\mathrm{Xu}$ Jianzhong}

Volume 50, numéro 3, août 2005

Le prisme de l'histoire

The History Lens

URI : https://id.erudit.org/iderudit/011611ar

DOI : https://doi.org/10.7202/011611ar

Aller au sommaire du numéro

Éditeur(s)

Les Presses de l'Université de Montréal

ISSN

0026-0452 (imprimé)

1492-1421 (numérique)

Découvrir la revue

\section{Citer cet article}

Jianzhong, X. (2005). Brief History of Science Translation in China. Meta, 50(3), 1010-1021. https://doi.org/10.7202/011611ar

\section{Résumé de l'article}

La traduction de la science est une discipline nouvelle en Chine, mais sa pratique remonte à l'an 200 avant J.-C. Elle contient tous les domaines pratiques à l'exception bien sûr de la traduction littéraire. L'objet de cette activité est essentiellement la transmission de l'information scientifique, soit une activité de la pensée, activité cognitive, de la part du traducteur qui assure le transfert de l'information de la langue source en langue cible. Selon une approche chronologique, cet article explore son évolution de la pratique à la théorie, de sa forme écrite à sa forme orale et de la théorie générale à la recherche disciplinaire. Cette étude se limite à la traduction humaine.
Ce document est protégé par la loi sur le droit d'auteur. L'utilisation des services d'Érudit (y compris la reproduction) est assujettie à sa politique d'utilisation que vous pouvez consulter en ligne.

https://apropos.erudit.org/fr/usagers/politique-dutilisation/ 


\title{
Brief History of Science Translation in China
}

\author{
XU JIANZHONG \\ Tianjin University of Technology, Tianjin, China \\ xujianzhong2003@yahoo.com.cn
}

\begin{abstract}
RÉSUMÉ
La traduction de la science est une discipline nouvelle en Chine, mais sa pratique remonte à l'an 200 avant J.-C. Elle contient tous les domaines pratiques à l'exception bien sûr de la traduction littéraire. L'objet de cette activité est essentiellement la transmission de l'information scientifique, soit une activité de la pensée, activité cognitive, de la part du traducteur qui assure le transfert de l'information de la langue source en langue cible. Selon une approche chronologique, cet article explore son évolution de la pratique à la théorie, de sa forme écrite à sa forme orale et de la théorie générale à la recherche disciplinaire. Cette étude se limite à la traduction humaine.
\end{abstract}

\begin{abstract}
Science translation is a new branch of learning in China, but its practice can be traced back to about $200 \mathrm{BC}$. It includes all the practical fields but literary translation. It is the translation activity that mainly conveys science information, especially a thought activity and extra-language activity of the translator's using target language to express the science information of source language so as to pursue the similar information. This paper briefly examines its history chronologically, and explores its gradual movement from practice to theory, from written translation to oral interpretation, from general theory to discipline studies. The history of science translation is composed of human translation and machine translation, but this paper only deals with the former.
\end{abstract}

\section{MOTS-CLÉS/KEYWORDS}

science translation, history, translation activity, translation studies, China

Science translation generally refers to the translation activity that mainly conveys science information, especially a thought activity and extra-language activity of translators' using target language to express the science information of source language so as to pursue the similar information. It is not technical translation or scientific translation, but non-literary translation, i.e., it includes all the practical fields but literary translation. The history of science translation comprises human translation and machine translation, but this paper just deals with the former.

\section{From Han Dynasty to Northern and Southern Dynasties (206 BC-589)}

\section{Translation activity}

Han Dynasty (206 BC-220) in China consists of Western Han (206 BC-24 AD) and Eastern Han (25-220), during which China had economic and cultural exchanges with West Asia, East Asia and South-East Asia by land and by sea. Zhang Qian (?-140 $\mathrm{BC}$ ) was sent by the government twice (in $138 \mathrm{BC}$ and $119 \mathrm{BC}$ ) to Xi Yu (Western Regions), now Xinjiang (China) and parts of Central Asia, beginning the economic 
and cultural exchanges between Han Dynasty and the Western Regions. Ban Chao (32-102) in Eastern Han Dynasty, by going along the new road on the northern slope of Tianshan Mountains (China), reached the Indian Ocean, the Persian Gulf and the Mediterranean Sea, thus promoting the communication between Han Dynasty and the countries of these areas.

In Three Kingdoms (220-280) China had some exchanges with some foreign countries such as Japan and $\mathrm{Da}$ Qin (ancient Rome). In Northern and Southern Dynasties 420-589) China sent its craftsmen and painters to Bai Ji (an ancient country in Korean Peninsula) and introduced musical instruments from Korea. Chinese techniques such as architecture, paper-making, textile, etc. were exported to Viet Nam, and Chinese silkworm breeding to Europe through Persia, while China imported the arts, medicine and phonology from India.

\section{Translation studies}

Oral translation of Buddhist sutra in China began with Yi Cun (?-?, doing the interpretation work around $2 \mathrm{BC}$ ), and written translation of it with An Shi Gao (?-?, in Eastern Han Dynasty, his translation work lasting from 148 to 172), the translation of important classics with $\mathrm{Fa} \mathrm{Hu}$ (?-?, his translation work lasting from about 230 to 308), and translation studies with Zhi Qian (?-?, his translation work lasting from 222 to 254) and Dao An (314-385). Zhi Qian, a monk coming to China in late Eastern Han Dynasty, was the first in China to probe into translation theory and techniques. His translation principle is being expressive and elegance and being acceptable to the readers. Dao An knew little about Sanskrit, but through the comparison of different translated versions he explored the law of translation such as complicated and concise, literal and liberal techniques, and proposed his theory "Five Adaptations and Three Difficulties." The five adaptations are 1) adapting in the light of the order of Chinese, 2) doing some polishing because of the plain Sanskrit and flowery Chinese, 3) not deleting the repetitions of the same thing in the original, 4) deleting the unnecessary repetition in the end of sutra, and 5) deleting the re-expressions of the things expressed previously before coming to other parts. The three difficulties are 1) it is hard to properly translate the ancient Sanskrit by using the Chinese rhythmical prose (characterized by parallelism and ornateness), 2) it is hard for the later generation to master the delicate philosophy of the ancients, and 3) it is hard for people at present to achieve accuracy in translating materials of the old days. Kumarajiva (350-409), based on Dao An's theory, founded the school of liberal translation, the first in China. Different from Zhi Qian's liberal translation of somewhat faithfulness to the original, he thought translation should be faithful to the original, but that didn't mean to copy the form of the original.

\section{From Sui Dynasty to Yuan Dynasties (581-1368)}

\section{Translation activity}

Sui Dynasty (581-618), Tang Dynasty (618-907) and Five Dynasties (907-960) saw the exchanges between China and the countries in Korean Peninsula such as Gao Li, Bai Ji and Xin Luo, not only in trade but education. Japan sent its students to study in China (Tang Dynasty) and returned with Chinese rites, calendar and music. 
Science translation in ancient China, especially in Sui and Tang Dynasties was often included in the translation of religious documents. From Eastern Han Dynasty to Tang Dynasty, about six hundred years, saw the flourishing age of the translation of Buddhist sutra, especially in the period of two hundred years from early Tang to Mid-Tang Dynasty. The formal translation of Buddhist sutra covered three important periods: 1) from Eastern Han (25-220) to Western Jin (265-316), 2) from Eastern Jin(317-420) to Southern Dynasty (420-589) and Northern Dynasty (386-581), and 3) Tang Dynasty (618-907) (with the most important translator Xuan Zang, the great monk in Tang Dynasty who devoted all his life to the study and translation of Buddhist sutra from Sanskrit to Chinese). Song Dynasty (960-1279) and Yuan Dynasty (1721-1368) strengthened the relationship with the neighbouring countries, and the economic and cultural exchanges were very active. At the same time China kept the good relations with some countries in the Middle East and Africa.

The feature of this period is more individual translation, more translations from foreign languages to Chinese, and more edited translations and reported translations.

\section{Translation studies}

Great monk Yan Zong (557-610) in Sui Dynasty proposed "Eight Requirements for Translators": 1) Love Buddhist sutra and make nothing of hardships, 2) be faithful and trustworthy, 3) master the theme and leave no doubt, 4) be knowledgeable, 5) be magnanimous and not arbitrary, 6) be indifferent to personal fame and wealth, 7) be good at Sanskrit and master its argumentation, and 8) be good at Chinese and be accurate in translation.

Great monk Xuan Zang (about 600-662) was against Kumarajiva's liberal translation, he blended the literal and liberal techniques. To him, faithfulness is the main concern. His criterion was being faithfulness and expressiveness. Besides, he put forward in his translation of Buddhist sutra the so-called "Five Non-translatable Categories": 1) mysterious ones, 2) polysemic ones, 3) non-existent in China, 4) following the customary saying, and 5) non-translatable ones. Actually he referred to transliteration.

\section{Ming Dynasty (1368-1644) and Qing Dynasty (1644-1911)}

\section{Translation activity}

From the 16th century China's science and technology began to fall behind the West. At the end of Ming Dynasty it was far behind. Matteo Ricco (1552-1610), due to the failure in doing missionary work in China, came up with an idea of doing it by way of disseminating science. He interpreted and Xu Guangqi (1562-1633) recorded some mathematical works, which was a great step forward in achieving his goal, thus beginning the first science translation climax in China. Many missionaries participated in the work such as Jules Aleni (1582-1649, Italian, coming to China in 1610), Emmanual Diaz Jr. (1574-1659, Portugal, coming to China in 1601), Adan Schall von Bell (1591-1666, German, coming to China in 1622), Francisco Sambiaso (1582-1649, Italian, coming to China in 1610), and Jacobus Rho (1593-1638, Italian, coming to China in 1624). Receiving instructions from the government Xu Guangqi (15621633) established $\mathrm{Li} J u$ (Almanac Bureau), the first science translation organization 
in China, in which Xu Guangqi, Li Zizao (1565-1630), etc., together with some foreign missionaries, translated and edited some astronomic works.

Over seventy famous missionaries came to China in late Ming Dynasty and early Qing Dynasty. They translated or translated and edited over 300 books, among which about 120 were science works. Since 1722 Ming Dynasty stopped doing missionary work in China, thus the next over 100 years saw little translation of science works.

In late Qing Dynasty Lin Zexu (1785-1850), Wei Yuan (1794-1856) and Xu Jishe (1795-1893) were the pioneers of translating scientific documents and had great influence on the history of modern China. They knew nothing about foreign languages, but they organized the translation activities (usually selective translation and edited translation) in order to know the outside world. Li Zexu organized the translation work to resist opium and to introduce international law. Wei Yuan, based on the translated materials, wrote a book on world history, geography and the foreign policies China should take. Xu Jishe, based on the translated and foreigners' oral materials, wrote a book of world geography.

The 19th century witnessed the translation activities of foreign missionaries. Some missionaries even set up translation organizations, among which the earliest and most influential was Mo Hai Shu Yuan (The London Mission Press) that was established in 1843. The workers in it are Wang Tao (1828-1899), Li Shanlan (18111882), Zhang Fuxi (?-1862), Alexander Wylie (1815-1887, English, coming to China in 1847), Joseph Edkins (1823-1905, English, coming to China in 1948), William Muirhead (1822-1900, English, coming to China in 1846), etc. Other organizations are Yi Zhi Shu Hui (The School and Text Book Series Committee), Guang Xue Hui (Society for the Diffusion of Christian and General Knowledge among the Chinese), etc.

The late Qing set up Tongwen Foreign Language School in order to foster translators and foreign affairs officials. 1867 saw the translation centre of Jiangnan Manufacturing Bureau, a translation and publishing agency, to develop modern China's war industry, which was initiated and founded by famous scientists $\mathrm{Xu}$ Tao (18181884) and Hua Hengfang (1833-1902). Xu Tao dealt mainly with chemistry and Hua Hengfang mathematics. The centre also invited foreigners in China as translators such as John Fnyer (1839-1928, English, coming to China in 1863), Alexander Wylie (1815-1887, English, coming to China in 1847), Daniel MacGowan (1814-1893, American, coming to China in 1843), Young John Allen (1836-1907, American, coming to China in 1843), Carl T. Kreyear (?-?, American, coming to China in 1866), Edward Thomas Williams (1854-1914, American, coming to China in 1887) and F. Huberty James (1856-1900, English, coming to China in 1883). 1901 saw anther translation centre, Jiangchu Compilation and Translation Bureau in Wuchang, with Zhang Zhidong (1837-1909) as its head.

The late Qing Dynasty sent Chinese students to study in foreign countries. When returned they became good translators of science translation. For example, Yan Fu (1853-1921) was sent to Britain in 1876 to study military, but he studied not only military but Western philosophy, sociology, evolution, laws, economy, and he did a lot of science translations when back home.

Many translation and publishing houses were established in late Qing Dynasty such as The Shanghai Commercial Press and Shanghai Translation Bureau. 


\section{Translation studies}

The science translation in late Qing Dynasty is the second science translation climax in China. The government and some people of insight thought it necessary to train translators, so they set up some translation organizations and translation centres, and offered translation courses. Yi Xue (translation studies) appeared first in the rules of Si Yin Guan (Translation School) established in 1644.

Science translation technique was one part of translation studies at that time. The theorists were Ma Jianzhong (1845-1900), Liang Qichao (1873-1929), Yan Fu (1853-1921) and Wang Guowei (1877-1927). Ma Jianzhong thought that only by understanding tacitly every link of the translation process can target readers have the same resonance as these of the original. Liang Qichao laid stress on liberal translation and thought that, taking consideration of the circumstances, science translation needs some kind of creation. Yan Fu, by studying the successful experience in translating Buddhist sutra from Sanskrit into Chinese and summarizing his own translation practice, put forward the three-word criterion, i.e. faithfulness, expressiveness and elegance, which was widely accepted in Chinese translation circles, and now which still has the practical significance. His other contribution is using translation variation (there was no such term at that time) in his translation practice, which has long been ignored by the translation circles. His three-word criterion makes clear the translation orientation, and his practice of translation variation supplies a guide to the down-to-earth translation practice. By translation variation, we mean it "is an activity aimed at deriving the theme or partial content of the original by using the appropriate adaptations such as expansion, deletion, summarization, explanation, supplement, combination and remoulding in the light of the special needs of the readers" (Xu J.Z. 2000).

The rise of science translation promoted the translation and compiling of bilingual science dictionaries, the first being bilingual scientific words and phrases, and bilingual dictionaries of science terms, which was pioneering and laid a solid foundation for the later compiling of various dictionaries.

Liang Qichao thought that quality translation needs appropriate source text, proper translation laws and techniques, and qualified translators, that two mistakes easily made in translation are distorting the meaning of the original in order to follow the Chinese norms and trying to follow the norms of the source language but making the translated version hard for target readers to understand, and that translators should grasp the real meaning of the original and express it in the light of Chinese norms in order to satisfy the need of the readers. His book How to Read Western Books was considered one of the most important books on translation critique, in which he commented on the content and quality of hundreds of translated books, and he also introduced translation organizations and translators. Wang Guowei, a translation critic, believed that it is hard to do a perfect translation because of the vague connotations of ancient Chinese and the difficulty in choosing equivalence between Chinese and English words. 


\section{Republic of China (1912-1949)}

\section{Translation activity}

The quantity of science translation in this period is much more than the last over seventy years in the late Qing Dynasty. The Republic of China established the formal book compilation and translation department. Its Education Ministry set up the National Compilation and Translation Centre that not only became the main force of compiling and translating books but also directed and coordinated the activities macrocosmically. The centre mainly handled textbooks from primary to college levels, advanced academic works, classics, science series and professional dictionaries. But it made few achievements since its establishment due to the successive national calamities including the civil war.

This period saw the return of many students from Europe, America and Japan who became the backbone of scientific research and teaching contingents thanks to their good command of Chinese, foreign languages and science knowledge. They were Yang Xingfo (1893-1933), Ma Junwu (1882-1939), Zhou Jianren (1888-1984), Zhang Ziping (1893-1959), Wang Guowei (1877-1927), Lu Xun (1881-1936), Wang Yunwu (1888-1979), Ding Xilin (1893-1974), Zheng Zhenduo (1898-1958), and others, some of whom established science associations, whose tasks including translating foreign science books, standardizing the translated terms and compiling science dictionaries. And those returning from France, Germany and Russia translated and introduced a lot of works of Marxism-Leninism, promoting the process of the Chinese revolution and the cause of social sciences. They were Wang Yifei (1898-1928), Wu Lanfu (1906-1988), Liu Renjing (1902-1987), Ren Bishi (1904-1950), Shen Zemin (1900-1933), Sheng Yanbing (1896-1981), Li Yimang (1903-1990), Li Dazhao (1889-1927), Wang Hanjun (1890-1927), Li Da (1890-1966), Li Lisan (1899-1967), Zhang Wentian (1900-1976), Chen Wangdao (1891-1977), Wu Liangping (1908-?), Zheng Chaolin (1901-1998), Luo Yinong (1902-1928), Luo Zhanglong (1896-1995), Zhao Shiyan (1901-1927), Liu Zhixun (1898-1932), Qin Bangxian (1907-1946), Qu Qiubai (1899-1935), Yun Daiying (1895-1931), Ai Siqi (1901-1966), and others.

This period witnessed the rapid development of non-governmental publishings, some famous ones being The Commercial Press, The China Publishing, The Life Publishing, The National Weekly, etc., which published many translated books.

During the Anti-Japanese War (1937-1945) and the third civil war (1945-1949) the Central Committee of the Communist Party of China set about fostering the diplomatic staff, translators and interpreters. 1940 saw the Foreign Languages School in Yan'an, Shaanxi. The publishing houses set up by the Communist Party of China translated and published a great many books of Marxism-Leninism and other science works.

\section{Translation studies}

Translation research in this period is done mainly by literary translators, and the exploration of science translation criterion and approaches were included in the discussion of literary translation. They explored which is better for science translation, literal or liberal; literal translation doesn't mean word-for-word translation and liberal translation doesn't mean translating according to one's will. Here the discussion of 
criterion was behind the discussion of approaches. Chen Xiying (1896-1970) in 1927 proposed the necessity of distinguishing non-literary translation from literary translation, and he thought the criterion for science translation or non-literary translation is faithful and expressive. Ai Wei (1890-1955) in the same year studied translation approaches by investigation, and compared literal and liberal translation by experiment. He is the first in China to do translation studies by a quantitative approach. There were a great many discussions on faithfulness and smoothness. As for science translation, Lu Xun (1881-1936), Qu Qiubai (1899-1935), Mao Dun (1896-1981), Ai Siqi (1901-1966) and Chen Kang (1902-1992) thought faithfulness is primary and smoothness secondary.

Zhu Ziqing (1898-1948) in 1919 examined translated names (terms) from aspects such as distinguishing transliteration from liberal translation, blending of transliteration and liberal translation, coining new words, transliteration and liberal translation. The discussions by Yang Duanliu (1885-1966), Fu Sinian (1896-1950), Guo moruo (1892-1978) and Lu Xun's (1881-1936) were centred on which is most important for science translators, science accomplishment, understanding of the source text, or the expression of the target text. They all believed science accomplishment is the most important. Fu Sinian proposed doing selective translation of the less important science works.

He Lin (1902-1992) in 1940 explored translation philosophically, discussed the translatable, the untranslatable, unnecessary translation and the worthless of translation, as well as the translated being equal to or even surpassing the original.

With the quantity increase of science translation and the increase of science terms and foreign names, it became necessary to standardize the terms and names. The government set up the Terms Standardizing Committee. Non-governmental organizations actively participated in the work. One of the achievements that resulted from term standardization was the compiling of a great many bilingual science dictionaries.

\section{The People's Republic of China (1949- )}

\section{Translation activity}

Science translation in this period has included three stages: pioneering, freezing and vitalizing.

\section{The pioneering stage (1949-1966)}

Due to the anti-Japanese War (1937-1945), China fostered less science workers and translators, and during the Third Civil War (1945-1949), many advanced science workers went to Taiwan. In order to meet the need of New China's construction, the government in 1950 established the Compilation and Translation Bureau of the Chinese Academy of Sciences. 1954 saw the birth of the Science Press that is one of the high-quality publishing houses producing foreign books and their translations. Among those scientists who returned from Europe and America, over 300 worked in the Chinese Academy of Sciences and became the fresh activists in New China's scientific work and the main force and directors of science translation.

During the 1950s there were very frequent exchanges between China and Russia. Many Russian experts and consultants came to China to help do the Chinese con- 
struction work. At the same time the Chinese government sent young and middleaged science workers to Russia for further studies. 1957 saw the agreement between China and Russia on 122 items of engineering technology. According to the agreement Russia would help China with 156 construction projects, which created the need of translators. Students graduated from Harbin and Dalin Russian Schools were welcomed everywhere, but they still could not meet the need.

Chinese science workers seldom went to attend the world symposiums for various reasons. The Beijing Science Symposium held in Beijing in 1964 was the most important world conference, with 367 representatives from 44 countries and regions in Asia, Africa, Latin America and Oceania. To meet the need of translators and interpreters for this meeting, the government assembled nearly 300 translation workers. It was a great event in China science translation history.

The early years of New China saw the flourishing of translating Russian works of social sciences. The People's Press, The Joint Publishing and The Commercial Press worked out sucessive plans to publish translations of social science works. 2796 translated works of social sciences were published from 1949 to $1954,33.7 \%$ of the total publishing. The Commercial Press in 1956 planned to publish 1378 works of social sciences in the next ten years, but it actually produced 437 due to various political movements.

The early years witnessed the establishment of the Beijing Foreign Languages Institute and Foreign Affairs College to train badly needed personnel for foreign affairs. Diplomatic relations between China and some other countries were established in 1957, and the government planned to foster over 400 senior translation workers. Zhou Enlai (1898-1976), the prime minister at that time, instructed the Foreign Ministry to train 1000 translation workers in the shortest possible time.

\section{Freezing stage (1966-1976)}

With the worsening of Sino-Russian relations and the return home of all the Russian experts, nearly all the initiated projects had to be abandoned. The launching of the unprecedented Great Proletarian Cultural Revolution (1966-1976) brought nearly all the translation work to a standstill. During this period everything had to be relinguished for the political movement including translation. The government assembled some translation workers to translate Mao Zedong's (1893-1976) Selected Works.

However, as long as the government stressed science and technology and needed the relevant foreign science information, the science translators silently did the work very well, especially in the work of National Defense.

Due to some special reasons the early 1970s saw four translated books of foreign social sciences. The government in 1971 planned to publish two series: one was history of individual country, the other geography of individual country. Up to 1978, 171 history books and 72 geography books had been produced. With the establishment of diplomatic relations with the United States, Canada and Italy in the seventies, especially the return of the seat of the People's Republic of China in the United Nations in 1971, China badly needed a great number of translation workers. The Ministry of Foreign Affairs urgently assembled large numbers of translators and interpreters to do the translation work. The government accordingly resumed sending students to study in foreign countries, who, upon their return, did foreign affairs work. 


\section{Flourishing stage (1977- )}

The ending of the Great Proletarian Cultural Revolution in 1976 marked the coming of a new era. The National Science Conference held in Beijing in 1978 brought life to the science circle, and science translation began to revive and flourish. Information centres were established in every corner of the country. Foreign language departments or institutes began to enroll students in increasing numbers in order to satisfy the needs of the rapid development.

The establishment of a Chinese Translators' Association in 1982 and of the SciTech Translators' Association of the Chinese Academy of Sciences in 1986 symbolizes the flourishing. Accordingly, every province set up its translators' association. This period witnessed an unprecedented increase in the quantity of science translation, with nearly 500,000 non-literary translation workers counted. Take the translation of social sciences as an example. The years 1978 to 1990 saw 28,500 translated works, 7,400 of these in the social sciences, mostly from the United States, Japan, Russia and Great Britain. The characteristics of the translation in the seventies and eighties are as follows: translation of Western academic works from the 16th to the 19th century, especially the translation of Marxism was systematized; translation of a moderate number of ancient Greek and Roman classics, translations of a wide range of modern and contemporary foreign academic works, varying in quality; and the emergence of young translators in large numbers. The publishing of translations of social science series on a large scale involved extensive planning.

With the introduction of advanced science and technology from other countries, science translators have been playing an ever increasingly important part in the nation's construction. And with the frequent economic and cultural exchanges with an increasing numbers of countries, translation workers are seen to perform well in every corner of the country.

The translation work has become much more prosperous since 1997. The policy of opening to the outside world brought a turn in history, i.e., the turning from "bringing in" to both "bringing in" and "sending out." And in this process translation serves as an extremely important bridge. Chinese science workers attend world meetings, including translation symposiums, at home and abroad and do more exchanges with the colleagues in the world. To satisfy the needs of the country's development, personnel fostering became increasingly important. Many foreign language universities appeared along with many translation departments or schools in universities, some of them offering a doctorate degree in translatology.

\section{Translation studies}

The first 15 years of the People's Republic of China saw the glory of science translation, but the translation circle focused its attention to literary translation. The ten years of the Great Cultural Revolution (1966-1976) hindered the development of science translation studies. So the initiation of science translation studies began with the period of China's opening to the outside world. The practice of science translation in the fifties and sixties laid a solid foundation for translation studies from the eighties on.

Translators' Notes (now Chinese Translators' Journal) started publication in 1980, the Shanghai Journal of Translators for Science and Technology (now Shanghai Translators' Journal) in 1986, and the Chinese Science \& Technology Translators Journal in 
1988, which open up vast fields of activity for science translation studies. That the Chinese Translators Association and Science \& Technology Translators Association of the Chinese Academy of Sciences became members of the International Federation of Translators (FIT) in 1987 and 1990 respectively demonstrates that Chinese translators and translation studies have assumed their place in the world translation circle. The Chinese Science \& Technology Translators Journal, at the XIII FIT World Congress held in Brighton on August 6-13, 1993, won the FIT Journal Prize for the best national journal of translation during 1990-1993, which shows translation studies in China has gained attention and approval from the international translation world.

The quantity of science translation work since the seventies has increased rapidly, becoming the largest, and people recognize the great part played by science translation. However, compared with its practice, science translation studies is much more backward.

1984-2004 saw eleven National Sci-Tech Translation symposiums, each demonstrating the trends of China's science translation studies. The National Chinese-Foreign Languages Translation Symposium has been held every year since 2000 by the Central Compilation and Translation Bureau, the Chinese Translators' Association and other organizations. Apart from the above two symposiums, various translation conferences are held here and there, which, more or less, tackle science translation studies. All these meetings promote the development of science translation studies.

More than 50 years' development in science translation and its studies moved gradually from practice to theory, from written translation to oral interpretation and to machine translation, from general theory to science translatology. The basic line of science translation in China is as follows: from basic approaches to basic theories, from morphology and syntax to discourse and style, from into Chinese to from Chinese, from linguistics to thought science, from general theory to discipline study, and from basic discipline to applied discipline.

Linguistics is the basic discipline to translation studies. Modern and contemporary linguistics offer a solid ground for translation activities and studies such as understanding process, extra-language transformation and expressing process. Science translation study introduces successively Transformative-Generative Grammar, pragmatics, semiotics, semantics and contrastive linguistics, etc.

Stylistics is indispensable to translation studies. The stylistic features of science translation are stylization, complication and wide coverage, so science translation must not only be highly logical, accurate and concise but also pay great attention to its rhetoric and symbols.

History research of science translation concerns translators, translators' products and translation studies. But there are a few researchers in the area such as Li Yashu (the Chinese Academy of Sciences), Li Nanqiu (China University of Science \& Technology) and Ma Zuyi (Anhui University). The works done mostly discuss what happened in Ming and Qing Dynasties (1368-1911), and they lay more stress on materials, and less on translation theory. History of Science Translation in China done by Li Yashu, Li Nanqiu et al is the only complete one that covers not only the period from the ancient to the present but also translators, translators' products and translation studies.

Applied theory is a very important part of science translation. The masterpieces in this area are Hu Gengshen's 'International Exchange and Foreign Language Application,' Xu Jianzhong's 'Enterprise Translation,' Huang Zhonglian's 'Translation 
Variation,' Li Zhaoguo's 'Translation of Traditional Chinese Medicine,' Chen Shibing's 'Financial Translation' and Xu Mingwu's 'News Translation.'

Multi-disciplinary probe is the trend of science translation research. Translation theorists and practitioners try to describe and explain the phenomena of science translation from various disciplines such as philosophy, thought science, terminology, psychology, aesthetics, informatics, fuzziness theory and evolutionism.

The rapid development of science translation practice greatly promoted the initiation and flourishing of its studies. With the history study and the summary of translation approaches, the system of science translation research stemmed from practice gradually became a discipline.

Science language is the variety of the language, having its correspondent features. Science translation possesses its unique connotations. There are plenty of discussions about the criterion of science translation, but the ideas are basically the same: Perfect translation means to reappear the content and form of the original, but the former is more important in science translation. Therefore, faithfulness is the most important aspect of science translation, including faithful to the meaning, mood and logic of the original, since the goal of science translation is to introduce new ideas, new techniques and skills, and new methods. So science translation means to express the information of the original.

Science translation is quite different from literary translation. It is characterized by objectivity, standardization, the scientific and reality. Moreover, it possesses historical inheritance, and promptness in development, so the common feature of various translation activities is the perfect blending of the two systems of linguistic symbols.

The question of whether or not science translation is a branch of learning sparks heated discussions. Zhou Yiping \& Li Yashu in 1996 explored the system of science translation theory that contains the basic theory, approaches and skills, and multidisciplinary study. The basic theory consists of its basic principles, its criterion, its comment, and its history that are all the special contents of science translation except the basic theory. The approaches and skills incorporate its process, its methods of handling science vocabulary, syntax, discourse, rhetoric and non-linguistic symbols, which are all the special objects of the study of science stylistics. The multi-disciplinary study examines the relations between science translatology and other relevant disciplines. The year 2003 witnessed Huang Zhonglian \& Li Yashu's Science Translatology that shapes its basic system (its nature, its category, its inner law, its basic principles, its criterion, its process mechanism, its basic unit, etc.) and its applied theory (its teaching, machine translation, edited translating science dictionary, its criticism, etc.) by studying the basic strategies and history, and by combining the general system of a discipline. The book exactly defines science translatology, devises the train of thought of establishing science translatology, thus shaping science translatology.

\section{REFERENCES}

Chen, B (2002): Financial Translation Practice, Beijing, China Translation and Publishing Corporation.

Hunng, Z. L. (2000): On Translation Variation, Beijing, China Translation and Publishing Corporation.

Huang, Z. L. (2002): Translation Variation Theory, Beijing, China Translation and Publishing Corporation. 
Hunang, Z. L. and LI, (2003): Science Translatology, Beijing, China Translation and Publishing Corporation.

LI, N. Q. (1993): Historical Data of Science Documents Translation in China, Hefei, China University of Science and Technology Press.

LI, N. Q. (1996): Historical Data of Science Translation in China, Hefei, China University of Science and Technology Press.

LI, N. Q. (1999): "Survey of Chinese Science Translation Activities in the Period of the Republic of China," Chinese Science and Technology Translators Journal 4, p. 42-45.

LI, N. Q. (2002): China Interpretation History, Qingdao, Qingdao Publishing House.

LI, N. Q. et al (1999): "Features of Achievements of Scientific Translation in China," Chinese Translators Journal, 3, p. 32-34.

LI, P. (2000): "A Study on Information Paradigm in Translatology," Chinese Science and Technology Translators Journal 3, p. 1-3.

LI, Y. S. and N. Q. LI, (2000): China Science Translation History, Changsha, Hunan Education Press.

LI, Z. G. (1993): An Introduction to Translation of Traditional Chinese Medicine, Xi'an, Northwest University Press.

LI, Z. G. and J. Z Xu (1999): “TCM Translation: An Analysis of the Principles,” Translatio 1, p. 5-19.

MA, Z. Y. (1998): A Brief History of Translation in China Before 1911 (second edition), Beijing, China Translation and Publishing Corporation.

MA, Z. Y. and Ren, R. Z. (1997): History of World's Translations of Chinese Writings, Wuhan, Hubei Education Press.

Xu, J. Z. (2000): “Translation Variation: A Future Trend," Translatio 4, p. 384-397.

Xu, J. Z. (2002): An Introduction to Enterprise Translation, Beijing, China Translation and Publishing Corporation.

Xu, M. W. (2003): News English and Its Translation, Beijing, China Translation \& Publishing Corporation.

Zнou, Y. P. and Y. S. Li (1996): “On Sci-Tech Translatology," Shanghai Journal of Translators for Science and Technology 4, p. 35-36. 